\title{
Buying Perfume in the Digital Age: A Study on E-Shoppers' Perceptions and Typologies
}

\author{
Belem Barbosa*, Mehdi Mahdavi, Zaíla Oliveira and \\ Valentina Chkoniya
}

\begin{abstract}
Manuscript type: Research paper

Research aims: This study aims to shed light on the factors that facilitate online purchase of perfume. It specifically: 1) explores the antecedents of online purchase behaviour in the case of experience goods; 2) analyses the motivations, perceived benefits and perceived risks associated with online purchase of perfume; and 3) identifies perfume e-shoppers' profiles.

Design/Methodology/Approach: A qualitative research approach involving interviewing 27 perfume e-shoppers from Brazil, Iran and Portugal was adopted.

Research findings: The findings of this study reveal that there are three types of perfume e-shoppers: 1) experienced e-shoppers, 2) bargain e-seekers, and 3) expert e-shoppers. Competitive prices, enjoyable online experiences and greater varieties of perfumes are among the perceived benefits that motivate the online shoppers. The
\end{abstract}

\footnotetext{
* Belem Barbosa is Assistant Professor at the School of Economics and Management of the University of Porto, Porto, Portugal. She is full researcher at the Research Unit of Governance, Competitiveness, and Public Policies (GOVCOPP), and invited researcher at CEF.UP Center for Economics and Finance at the University of Porto. Email: marketing.belem@gmail.com Mehdi Mahdavi is graduate student of marketing from Faculty of Management and Economics, Science and Research Branch, Islamic Azad University of Tehran, Tehran, Iran. Email: m_mahdavi1982@yahoo.com

Zaíla Oliveira is Associate Professor at Christus University Center (UNICHRISTUS) and Fametro University Center (UNIFAMETRO), Fortaleza, Brazil. Email: zailaoliveira@gmail.com Valentina Chkoniya is Invited Adjunct Professor at the Higher Institute of Accounting and Administration (ISCA-UA), University of Aveiro, Aveiro, Portugal. Email: valentina. chkoniya@ua.pt
}

Acknowledgement: The authors would like to thank the editor and the reviewers for their constructive comments which helped enhance the quality of the final version of the article

https://doi.org/10.22452/ajba.vol14no1.1 
inability to test the perfumes, particularly those that are never tried before, appears to be the major drawback.

Theoretical contribution/Originality: This study provides interesting cues on a topic that has so far been disregarded by the literature despite its growing importance as a business sector - online purchase of perfumes. It offers the categorisation of three e-shopper profiles, based on consumers' narratives, and highlighted the importance of further addressing the dynamic nature of consumer behaviours, particularly in the online context.

Practitioner/Policy implications: The findings show that the main trigger of buying perfume online is the price discounts, which is particularly important to less experienced Web shoppers. This indicates that experience goods such as perfume should, at the initial stage, be sold in stores that offer an assortment of products. Online perfume stores should consider alternatives to provide perfume testing.

Research limitation/Implications: Purposive sampling does not allow results' generalisation; hence future research is needed to further validate the findings.

Keywords: E-shoppers' Motivations, Experience Goods, Online Shopping, Perceived Benefits, Perceived Risks, Perfume

JEL Classification: M10, M30, M31

\section{Introduction}

The advantages of online shopping are widely accepted. Indeed, through online shopping, consumers enjoy the benefit of convenience and price comparison features (Ayanso et al., 2010). The Covid-19 outbreak, which was first reported by China to the World Health Organisation on December 31, 2019, and had been declared as a global pandemic on March 11, 2020, has a large effect on shopping behaviours. Given that the majority of physical stores are forced to close temporarily and consumers have reservations about travelling to brick-and-mortar stores due to health concerns, the demand for Internet shopping rose quickly in the short term (UNCTAD, 2020). Many consumers have now migrated to the digital world by shopping frequently online.

Despite the advantages of online shopping, scholars like Phau and Poon (2000), Levin et al. (2003), Zhang et al. (2018) argued that brickand-mortar outlets cannot be replaced by their online counterparts for certain range of products because the Internet limits the use of senses such as smell and taste. For some types of products, consumers value the opportunity to physically check the products before buying them. 
Products such as perfumes and shoes, for example, require direct involvement of olfactory and haptic senses. While many have contested the suitability of products such as cosmetics and perfumes to be offered online, surveys conducted by Clement (2020), Eurostat (2018) and Nielsen (2018) showed these products to be among the most popular online purchases; thus creating an urgent need for online sellers to understand consumer motivations and perceptions.

Within the literature, there are studies that found both perceived benefits and risks as influencing factors for online shopping (Zhang et al., 2017). The inability to physically access the products (Nakayama et al., 2010; Dai et al., 2014) and the absence of sales associates (Dai et al., 2014) to facilitate the buying process are considered risk factors. In Portugal, Silva et al. (2019) found perceived risks to have a negative effect on e-shoppers' trust, which consequently leads to low acceptance of online shopping. In a recent study, Guru et al. (2020) identified performance risk, financial risk and time-loss risk as three important barriers to the growth of online shopping in India. The literature review highlights that various studies have been conducted on online shopping and found perceived risks and benefits to be important factors. Despite the insights offered by these studies, there is limited study on perfume products.

The gaps identified in the literature motivated the authors of this present study to focus on perfume products. According to Grand View Research (2019a), perfume has emerged as a very significant business sector in recent years due to improving living standards around the world and the growing trend of personal care consumption. The perfume market is expected to reach US $\$ 40.9$ billion by 2025 and grow at an average rate of 3.9 per cent (Grand View Research, 2019b). Statista also forecasts a gradual growth in the global fragrance market from US\$38.1 billion in 2013 to US\$52.4 billion in 2025 (Shahbandeh, 2019). Additionally, consumers' preference to buy perfume online is expected to grow at an average rate of 3.9 per cent annually in the coming years (Grand View Research, 2019a; 2019b). Apparently, marketing communication strategies, such as advertising and promotions, are helping to attract more and more perfume users to online stores, even though they cannot test it. Considering the potential of the perfume online market, there is, therefore, an urgent need to develop and reinforce their online presence. The stakeholders need to develop effective marketing strategies to promote consumer purchasing behaviours. Hence, understanding consumer motivations for online perfume shopping is a prerequisite. 
This study aims to fill this research gap by tackling the following research question: What are the factors that facilitate online purchase of perfume? In line with this, the research objectives are as follows: 1) to explore the antecedents of online purchase behaviour in the case of experience goods; 2) to analyse the motivations, perceived benefits and perceived risks associated with online purchase of perfume; and 3) to identify consumer profiles of perfume e-shoppers.

This study makes several contributions. First, despite the fact that perfumes and cosmetics are among the products most purchased online, studies on perfume shopping behaviours are scarce, particularly those involving e-commerce. Hence, this study offers the systematisation of contributions scattered in the literature that help understand online shopping behaviours regarding perfumes. It also provides empirical evidence of this phenomenon by analysing first-hand narratives of e-shoppers' experiences. By collecting data from three countries, namely Brazil, Iran and Portugal, this study provides additional support and validation of contributions by extant literature. Moreover, this study distinguishes three types of perfume e-shoppers (the experienced e-shoppers, the bargain e-seekers, and the expert e-shoppers). They should be approached by deploying specific marketing strategies. This study suggests a dynamic trend in perfume e-shoppers' profiles that are determined by their overall shopping experience and the strategies to overcome perceived risks. Overall, this study offers valuable cues for both academics and practitioners involved with perfume and other experience goods' e-commerce behaviour.

The remainder of this paper is organised as follows: the next section presents the most relevant contributions in the literature regarding e-shopping behaviour, with a particular focus on experience goods. Sections 3 and 4 describe the method and the results of a qualitative study that was carried out in three countries, respectively. Sections 5 and 6 discuss the findings and implications for managers.

\section{Literature Review}

\subsection{Underpinning Theories}

This study was guided by three underpinning theories - Ajzen's (1991) Theory of Planned Behaviour, Hofstede's Cultural Theory (1991), and Unified Theory of Acceptance and Use of Technology (UTAUT) proposed by Venkatesh et al. (2003). 
According to the Theory of Planned Behaviour, the purchasing behaviour of consumers is determined by their attitudes, which reflects their valuation behaviour as favourable or unfavourable. A subsequent extension of this theory by Pavlou and Fygenson (2006) and Ha et al. (2019) argued that factors such as perceived usefulness, ease of use, download delay, website navigability, information protection, and product value could be used as predictors of e-shoppers' e-commerce adoption; hence demonstrating the complexity of factors that explain online behaviours. In the digital age, consumers often receive both positive and negative reviews of products sold online through the social media. They use these reviews to compare the benefits and risks before making purchase decisions (Ing \& Ming, 2018). They are expected to form favourable attitudes when they perceive the benefits to be more than the risks.

Since this present study involves data from three countries that have different cultures, the researchers adopted Hofstede's Cultural Theory. Past studies on purchase decisions have found that cultural differences between countries play a role in determining the perceptions of services received in shopping malls (Diallo et al., 2018; Thomas \& Carraher, 2014). Hence, retailing strategies should vary according to these differences (Thomas \& Carraher, 2014). One of the key areas of Hofstede's Cultural Theory that has been focused on is uncertainty avoidance, which can be defined as the extent to which the members feel threatened by ambiguous situations, creating negative beliefs (Hofstede, 2020). Hence, in the present study, attempts are made to investigate whether the frequency of mentioned perceived risks by e-shoppers vary among participants with different cultures in the three countries being studied. Meanwhile, Ko et al. (2004) considered uncertainty avoidance as the most important element in relation to perceived risks by e-shoppers since this factor appeared to reflect a culture's tolerance or intolerance of uncertainty. Data from Hofstede Insights $(2020)$ revealed Brazil's score of uncertainty avoidance to be 76, Iran's (59), and Portugal's (99). Hence, it is predicted that such discrepancies in uncertainty avoidance have relationships with perceived risks of online shopping of perfume among the interviewees.

The third theory, UTAUT, suggests that participants with different demographic profiles would report differently on their perceived risks and benefits of information systems/technologies (Chang et al., 2016). Since the samples used for the present study comprise participants with different demographic profiles, it is expected that they may perceive online perfume shopping behaviours differently. 


\subsection{Online Shopping Behaviour, Experiences, Motivations, Perceived Benefits and Perceived Risks}

Nguyen et al. (2018) summarised online consumer behaviour as a process of problem recognition, information search, evaluation, choice and outcomes in an online setting. Additionally, they interpreted consumer behaviour as a three-stage process of purchase, repurchase and product return. Given the technological development levels of different countries, Clemons et al. (2016) found that shoppers in more developed countries tended to show the same behaviour both in online and offline shopping environments. Likewise, in developing countries, shoppers might view online and offline outlets similarly, only if the brand has reputable quality.

The role of perceived benefits and risks in explaining e-shoppers' shopping behaviour and predicting intention to continue online purchase was highlighted in various studies. Some studies recognise both functional motivations and non-functional motivations as determinants of online shopping (Bhatnagar \& Ghose, 2004; Childers et al., 2001; Ganesh et al., 2010; Menon \& Kahn, 2002). Forsythe et al. (2006) concluded that hedonic component of online purchase is an important benefit for e-shoppers. While functional motives might include features such as financial incentives related to saving money via price promotions (Close \& Kukar-Kinney, 2010), non-functional motives are associated with adventure shopping, gratification shopping, idea shopping and value shopping (Arnold \& Reynolds, 2003). For example, overcoming bad moods, stress-relief or indulgence in a self-gift are considered as highlights of gratification shopping (Arnold \& Reynolds, 2003). For individuals who do not have the financial means or purchase intentions at the time of browsing the Internet, they would feel enjoyable by merely putting products in online shopping carts (Wolfinbarger \& Gilly, 2001). Study by Punj and Moore (2009) found that easy search of products is the major motivation for online shopping. Moreover, Shergill and Chen (2005) stated that price comparison, product features, and aftersales services that consumers might receive from the online vendors, are also the features besides product purchase that e-shoppers benefit from the Internet shopping experience. Based on the extant literature, Rohm and Swaminathan (2004) concluded that several motivations such as time saving, information seeking, and social interaction gained from shopping, recreational aspect of shopping, variety seeking, and desirability of immediate possession may be used to classify 
e-shoppers. In recent studies, Silva et al. (2019), Sharma et al. (2019) and Zhang et al. (2017) found that the possibility of saving both time and money, accessibility to a broader range of products, and the ability to compare different offers were among the perceived benefits of online shopping. Avoidance of queues, efficiency of time spent, and 24-hour access to the online outlets were also found to be valued by e-shoppers (Karayanni, 2003; Ganesh et al., 2010). In Vietnam, for instance, Bình (2018) discovered better quality, affordable prices, convenience and ease of purchase as factors that motivated shoppers to buy unofficial parallel imported products (UPIP) on Facebook.

Interestingly, several studies (Bhatnagar \& Ghose, 2004; Lee et al., 2019) revealed that e-shoppers are more concerned about online purchase perceived risks than the perceived benefits. Factors such as risk perception of, control over, convenience of the shopping process together with customer service and user friendliness of the shopping website, were demonstrated to be the reasons why some people avoid buying online (Vellido et al., 2000). One of the reasons for this apprehension is the lack of direct interactions between shoppers and product sellers (Nepomuceno et al., 2014). The lack of such physical contact with sellers in online platform worries e-shoppers, as some online stores do not have physical presence and the only way of contacting them is via phone or email, which in turn is perceived as poor after-sales services (Teo, 2006). Silva et al. (2019) discussed several sources of online perceived risks such as personal data and financial transaction security, product performance as well as fake and smuggled products. In the Facebook context, Bình (2018) reported several risks that the participants were concerned with, including having no basis for trying the products, low quality and fake products. The study indicated that the perceived risks associated with the products and sellers were higher when compared with the transaction and financial risks. Taking into account pivotal factors affecting consumers' online shopping behaviour, Chang et al. (2016) illustrated that online purchase intention can be adversely affected by perceived risks of shopping on the Internet. They added that online provision of details of product trials is necessary as by increasing consumers' familiarity with both the website and products, purchase intention of online products could be raised. Shergill and Chen (2005) believed that lack of physical checking of products' quality prior to purchase on the Internet is a serious risk that e-shoppers need to undertake. Furthermore, the need for physical checking of experience goods is responsible for lower purchase intentions among 
e-shoppers (Chiang \& Dholokia, 2003). Considering specific purchase behaviour of product types on the Internet, Verhagen and Bloemers (2018) suggested that it is most probable that e-shoppers of experience, high and low-involvement products use the think-feel-do hierarchy rather than feel-think-do hierarchy.

Creating exceptional customer experience represents a key element pursued by companies (Verhoef et al., 2009). As explained by Gentile et al. (2007, p. 397), "the customer experience originates from a set of interactions between a customer and a product, a company, or a part of its organisations, which provoke a reaction. This experience is strictly personal and implies the customer's involvement at different levels (rational, emotional, sensorial, physical, and spiritual)". By taking into consideration the significance of website designs in the contemporary era, Bleier, et al. (2019) believed that inducing effective e-shoppers' experience, which plays a crucial role in online sellers' achievement, could be fulfilled through design elements on product websites. Design elements like colours, images, videos, typography, navigation and layout would communicate pertinent information, entertainment, and social interactions aspects while trying to simulate sensory experiences similar to those experienced in brick-and-mortar stores (Zhai et al., 2017). Research has proposed that a combination of e-shoppers' cognitive and affective perceptions can be used in online personalised stores as a predictor of online shopping behaviour (Pappas et al., 2016). Furthermore, Bilgihan et al. (2016) argued that companies' survival in today's market competition depends on exceptional online purchase experience. Verhoef et al. (2009) suggested that affective, social, emotional, cognitive and physical nature as features of customer purchase experience.

Overall, the literature gives important cues that enables a framework for this study. Remarkably, online shopping experience is multidimensional, enabling distinct perspectives and approaches and ultimately various profiles of consumers. Accordingly, the extant literature points out both functional and non-functional motivations associated with online shopping, and although the perceived benefits are generally acknowledged for both search and experience goods, arguably the perceived risks (e.g. inability to test products before purchase) stand out regarding experience goods such as perfume. Consequently, motivations, perceived risks and perceived benefits are highlighted as indisputable factors that explain online purchase behaviours for different types of products, and that could help characterise and compare segments of e-shoppers. Table 1 summarises the literature. 
Table 1: Motivations, Perceived Benefits/Risks, and Dimensions of Online Shopping Derived from Past Research

\section{Consumer behaviour Findings from Literature variables}

Motivations

- Functional motivations: convenience, variety, quality, and price (Bhatnagar \& Ghose, 2004; Childers et al., 2001; Menon \& Kahn, 2002; Ganesh et al., 2010; Bình, 2018)

- Authenticity, originality (Bình, 2018)

- Non-functional motivations: social and emotional needs for enjoyable shopping (Bhatnagar \& Ghose, 2004; Childers at al., 2001; Menon \& Kahn, 2002; Ganesh et al., 2010)

- Hedonism (Forsythe et al., 2006; Ganesh et al., 2010)

- Enjoyment seeking (Wolfinbarger \& Gilly, 2001; Ganesh et al., 2010)

- Social interactions, Recreational aspects of shopping, Variety seeking, Desirability of immediate possession (Rohm \& Swaminathan, 2004; Ganesh et al., 2010; Zhai et al., 2017)

$\begin{aligned} \text { Perceived benefits } \quad \text { - } & \text { Shopping convenience (Sharma et al., 2019; Vellido } \\ & \text { et al., 2000; Zhang et al., 2017) and 24-hour-access } \\ & \text { (Karayanni, 2003) } \\ - & \text { Search convenience (Ayanso et al., 2010; Rohm \& } \\ & \text { Swaminathan, 2004) } \\ - & \text { Price comparison (Ayanso et al., 2010; Shergill \& } \\ & \text { Chen, 2005) } \\ - & \text { Saving money (Close \& Kukar-Kinney, 2010; Sharma } \\ & \text { et al., 2019; Zhang et al., 2017) } \\ - & \text { Increased variety (Sharma et al., 2019; Zhang et al., } \\ & 2017) \\ - & \text { Saving time (Karayanni, 2003; Rohm \& Swaminathan, } \\ & 2004) \\ - & \text { Avoiding queues (Karayanni, 2003) } \\ - & \text { Ease of locating (Ayanso et al., 2010) } \\ - & \text { Product features (Shergill \& Chen, 2005) } \\ - & \text { After sales services (Shergill \& Chen, 2005) and } \\ & \text { customer service (Vellido et al., 2000) } \\ - & \text { Control over the shopping process (Vellido et al., } \\ & \text { 2000) }\end{aligned}$


Table 1: Continued

Consumer behaviour Findings from Literature variables

\begin{tabular}{ll} 
Perceived risks & Lack of physical access to the products (Dai et al., 2014; \\
& Nakayama et al., 2010; Nepomuceno et al., 2014) and \\
& consumers' inability to test products before purchase \\
& (Chiang \& Dholokia, 2003; Phau \& Poon, 2000; \\
& Shergill \& Chen, 2005; Zhang et al., 2018; Bình, 2018) \\
- & Lack of physical contacts with sellers (Dai et al., 2014; \\
& Nepomuceno et al., 2014; Teo, 2006) \\
- & Waste of time and money (Silva et al., 2019) \\
- & Personal data security and financial transaction \\
& security (Silva et al., 2019) \\
- & Product performance, fear of buying fake and \\
& smuggled products (Silva et al., 2019; Bình, 2018) \\
\hline Dimensions of online - & Rational, emotional, sensorial, physical, and \\
shopping experience & spiritual (Gentile et al., 2007) \\
- & Information communication, entertainment, social \\
& interactions, sensory experience (Bleier et al., 2019) \\
- & Affective, Social, emotional, cognitive, physical \\
& (Verhoef et al., 2009) \\
- & Adventure shopping, Gratification shopping, Idea \\
shopping, Value shopping (Arnold \& Reynolds, 2003)
\end{tabular}

\section{Methodology}

Based on the contributions by existing literature and in order to fulfil the objectives of this study, we conducted a qualitative study involving consumers with some degree of experience in buying perfume online. Qualitative method was chosen since it serves as a useful tool to obtain detailed information and insights on consumers' points of view and personal experiences (Bryman, 2012; Gray, 2004; Seidman, 2013). Considering the scarcity of literature on e-shopping behaviours of experience goods, in particular, perfume, a qualitative exploratory approach was adopted.

This study was conducted in Brazil, Iran and Portugal. The reason for selecting the three countries were based on the fact that official figures from the International Telecommunication Union (ITU) and Organisation for Economic Co-operation and Development (OECD) 
show a growing trend in terms of Internet access (Country ICT Data, n.d.) and online purchase (OECD, 2017) in these three countries. Similarly, Statista (2020) presented specific data regarding the three countries under study. Revenue from the fragrances segment was estimated to reach US $\$ 4,937.5$ million by the end of 2020 in Brazil, while the figures for Iran and Portugal were estimated to be US\$537.1 million and US\$223.9 million, respectively. In addition, annual market growth of fragrances is expected to reach 5.9 per cent in Brazil, 5.5 per cent in Iran, and 8.8 per cent in Portugal, all of which are higher than the global average of 3.9 per cent. As aforementioned in the introduction, the three countries also present distinct profiles regarding uncertainty avoidance (Hofstede Insights, 2020). Finally, while Portugal, in Europe, offers much facilitated context to online shopping both in the European Union and from other international e-commerce platforms such as those by Chinese and American providers, Brazil, in South America, faces economic and structural constraints, typical characteristics of a developing country. Likewise, Iran, in Asia, has to deal with international sanctions that limit access to imported products, including from international e-commerce. These show that the three countries are associated with a dynamic and growing perfume sector in an interesting context.

A purposive sampling technique was adopted for the study. Drawn on the researchers' personal and professional networks, consumers who had shopped perfume online were identified and invited to participate in the study. As noted by Bryman (2012), the selection of individuals in a purposive sample is non-probabilistic and is guided by the research goals and the questions posed. The participants were strategically chosen because of their relevance to the topics being explored, in our case their experience in online purchase of perfume. Hence, purposive sampling should not be considered as convenience sampling (Bryman, 2012). In this study, both demographic characteristics and typography of online shopping profiles were considered when selecting participants to ensure sample diversity, which help provide additional validation (Bryman, 2012; Gray, 2004).

Semi-structured interviews were then conducted and audio recorded. Participation was anonymous, voluntary and confidential. All identifications were either omitted or replaced by pseudonyms. All copies of the audio records were destroyed after the analysis was completed. Transcriptions were subject to thematic content analysis, which was performed independently by two of the researchers. An initial list of categories guided by the literature was prepared, and the researchers 
did a line-by-line analysis of the interview transcripts for initial coding. They labelled sections of text that were aligned with the list of codes initially defined, but also added interpretative codes to sections that either appeared to be particularly salient in the participants' narratives or had potential for theoretical significance (Bryman, 2012). Hence, new themes emerged from the first round of codification. For instance, new themes were identified concerning the dynamism of online purchasing behaviour, as several participants explained in detail that they had gained experience in online shopping for general products before making their first online purchase of perfume. This pertained to distinct e-shopper behaviour. The resulting coding by each researcher was compared to identify and resolve incongruences. The data was then re-analysed based on the list of themes that came about from the first round of coding. Connections between the different codes were also explored, which resulted in the categorisation of three profiles of perfume e-shoppers. The analysis was done for each country separately and the results were compared in order to explore possible differences and similarities between them. Then the same procedure was applied considering the three profiles that emerged in order to further explore the connections between the themes.

Participants in this study comprised 11 men and 16 women aged 20 to 59 (Table 2). Nine participants from each country were interviewed face-to-face. The frequency of participants' online buying also varies, from infrequent (e.g., once or twice a year) to regular online shopping (e.g., monthly). The majority $(n=16)$ stated they frequently shopped online. Cosmetics, including perfume, clothing and electronics were reported by the interviewees as the usual categories of products they purchased online. It was also evident that both national and international e-tailers were targets for the participants regarding their online purchase activities. More than half of the participants $(n=17)$ were frequent buyers of perfume on the Internet, while 10 of them reported themselves as occasional buyers of scent products.

\section{Results}

\subsection{Online Shopping Behaviour, Motivations and Perceived Benefits}

To fully understand perfume e-shoppers' consumer behaviour, it is important to briefly analyse their relationship with online shopping in general. As depicted in Table 2, participants in this study had 
Table 2: Sample Characteristics

\begin{tabular}{|c|c|c|c|c|c|c|}
\hline Code & Age & Gender & Occupation & $\begin{array}{l}\text { Frequency of } \\
\text { Buying } \\
\text { Perfume } \\
\text { Online }\end{array}$ & $\begin{array}{l}\text { Frequency of } \\
\text { Online } \\
\text { Shopping } \\
\text { Activity }\end{array}$ & $\begin{array}{l}\text { Type of } \\
\text { Online } \\
\text { Stores }\end{array}$ \\
\hline BR1 & 42 & $\mathrm{~F}$ & Teacher & Occasionally & Frequently & Both \\
\hline BR2 & 48 & $\mathrm{~F}$ & Manager & Frequently & Frequently & National \\
\hline BR3 & 27 & $\mathrm{~F}$ & Clerk & Frequently & Frequently & International \\
\hline BR4 & 47 & F & Clerk & Occasionally & Occasionally & International \\
\hline BR5 & 34 & F & Psychologist & Frequently & Occasionally & National \\
\hline BR6 & 33 & M & Business owner & Occasionally & Frequently & Both \\
\hline BR7 & 47 & $\mathrm{~F}$ & Beautician & Occasionally & Frequently & Both \\
\hline BR8 & 50 & F & Hairdresser & Occasionally & Occasionally & Both \\
\hline BR9 & 49 & $\mathrm{~F}$ & $\begin{array}{l}\text { Purchasing } \\
\text { manager }\end{array}$ & Occasionally & Occasionally & Both \\
\hline IR1 & 30 & M & Self-employed & Frequently & Frequently & National \\
\hline IR2 & 22 & M & Pilot & Frequently & Occasionally & Both \\
\hline IR3 & 29 & M & Teacher & Occasionally & Occasionally & National \\
\hline IR4 & 28 & M & Clerk & Frequently & Frequently & Both \\
\hline IR5 & 24 & M & Student & Occasionally & Frequently & National \\
\hline IR6 & 28 & $\mathrm{~F}$ & Accountant & Occasionally & Occasionally & National \\
\hline IR7 & 28 & M & Coach & Frequently & Occasionally & National \\
\hline IR8 & 35 & M & Business owner & Frequently & Frequently & Both \\
\hline IR9 & 24 & $\mathrm{~F}$ & Beautician & Frequently & Occasionally & National \\
\hline PT1 & 22 & $\mathrm{~F}$ & Student & Frequently & Frequently & $\begin{array}{l}\text { Mainly } \\
\text { national }\end{array}$ \\
\hline PT2 & 24 & M & Student & Occasionally & Frequently & $\begin{array}{l}\text { Mainly } \\
\text { international }\end{array}$ \\
\hline PT3 & 26 & $\mathrm{~F}$ & Translator & Frequently & Frequently & Both \\
\hline PT4 & 59 & $\mathrm{~F}$ & Unemployed & Occasionally & Occasionally & Both \\
\hline PT5 & 24 & $\mathrm{~F}$ & Clerk & Frequently & Frequently & International \\
\hline PT6 & 20 & $\mathrm{~F}$ & Student & Frequently & Frequently & International \\
\hline PT7 & 48 & M & Shopkeeper & Frequently & Frequently & Both \\
\hline PT8 & 24 & $\mathrm{~F}$ & Clerk & Frequently & Frequently & Both \\
\hline PT9 & 50 & M & Business owner & Frequently & Frequently & Both \\
\hline
\end{tabular}

Note: $\mathrm{F}=$ Female, $\mathrm{M}=$ Male.

diversified shopping experiences, ranging from those who only bought one category of products online (e.g., Participant PT4 and PT5) to those who bought a variety of products, as in the case of Participant BR3 who stated that "I'll buy anything online". Participants noted that their online shopping behaviours had become more frequent in recent years, with some of them revealing they had changed their shopping from brick- 
and-mortar stores to online ones. In fact, some participants said this had become their preferred shopping channel. Yet many of them still use brick-and-mortar stores to assist the buying decision process. Some responses are provided as evidence:

Before that, I would not buy online, but since the past couple of years I have been doing it more frequently (BR2).

I usually try to buy online. In fact, before I make my purchase online, for example for clothes, I first try it out in physical stores and then place the order online. I usually search for items in physical stores and finally buy them online (IR4).

This study found access to online stores differs between countries, as participants from Iran and Brazil often claimed limited access to international online stores due to taxation, custom duties, costly returns and e-commerce policy issues. With regards to the motivations of online shopping, the respondents tended to emphasise on functional motivations like convenience and financial benefits. Some of them highlighted that they bought the products they needed or wanted online because of the lower prices. They explained that price differences between online and offline stores were particularly obvious for products such as electronics and perfume. There were also participants who said their growing preference for online shopping was due to their dislike for the physical stores' environment. They highlighted the positive feelings associated with online shopping as a trigger for them to choose the digital channel. These responses appeared to be in line with studies by Bhatnagar and Ghose (2004), Menon and Kahn (2002) and Bình (2018). The responses below illustrate this point:

Buying online gives you a particular type of joy (IR8).

Oh, it is so easy, I choose everything without leaving my home, without dealing with the traffic, without getting tired. And generally, I also get a larger choice and better prices (BR6).

Clemons et al. (2016) suggested that online and offline behaviours tended to be similar in the most technologically developed countries and in the case of highly reputable online settings. Apparently, in the case of experience goods such as perfume, differences in behaviour tended to be significant, except in the case of repurchase behaviour (Nguyen et al., 2018). Indeed, frequent perfume e-shoppers were particularly comfortable with the online settings as well as in the case of repeated 
purchases of a certain type of perfume (i.e., brand and fragrance). It should be noted that these findings did not vary between the three countries analysed.

\subsection{Perfume Online Shopping Experience}

Unsurprisingly, online purchases of perfume are facilitated by the overall online experience. For instance, participants IR8 and BR9 mentioned they had bought perfume online for the first time accidentally.

Actually, I wanted to buy [in an online store] some other things and decided to buy that perfume online, too (IR8)

As my experience of buying online is positive, I thought, why not buying also perfumes and enjoy more affordable prices than the ones in the physical stores? And then after a first nice experience I decided to continue buying perfume online (BR9).

As evidenced in the data, this behaviour is usually associated with discount offers. Indeed, one main reason mentioned by all participants in this study for buying perfume online is purchasing at more affordable prices. Take for instance the case of participant BR1 who mentioned:

It started because I used to always buy online. I lived in the US. (...) [Online you can find] really is cheap prices... more affordable. When I came back to Brazil, 3 years ago, I realized that here perfume was very expensive, but if you keep an eye on these websites, eventually you will get good prices, as good as in the USA... (BR1)

Access to a greater variety of products (in this case perfume products and brands) was also found to be an important reason for shopping online, confirming the findings by Sharma et al. (2019) and Zhang et al. (2017). Interestingly, some participants mentioned that physical stores also led customers to their online presence, as mentioned, for instance, by participant PT1:

My perfume sold out and the saleswoman told me, look, why don't you try to see if it is available online? And I think it was from there on that I started buying perfume online (Interviewee PT1).

Several participants admitted that they started buying from the online stores of the retailers they usually buy perfume from. Still, the quest for the lowest prices often led them to e-tailers, including unknown international retailers, as declared by participant PT9, for instance: 
Consumer behaviour variables
Findings

Convenience (BR1, BR2, BR3,

BR6, BR7, BR9, PT1, PT3, PT5,

PT7, PT8, PT9)

Price/Saving money (BR1, BR6, IR1, IR2, IR3, IR4, IR5, IR6, IR7, IR8, IR9, PT4, PT5, PT6)
Supporting Studies

Bhatnagar and Ghose (2004),

Childers et al. (2001), Menon and Kahn (2002)

Bhatnagar and Ghose (2004), Childers et al. (2001), Menon and Kahn (2002), Close and KukarKinney (2010), Silva et al. (2019), Sharma et al. (2019), Zhang et al. (2017)
Variety (BR2, BR5, BR6, BR8, IR1, IR2, IR6, IR7)

Bhatnagar and Ghose (2004),

Childers et al. (2001), Menon and Kahn (2002), Silva et al. (2019), Rohm and Swaminathan (2004), Sharma et al. (2019), Zhang et al. (2017)

Saving time (BR1, BR7, IR2, IR3, Silva et al. (2019), Rohm and IR5, IR7, IR9, PT9) Swaminathan (2004), Karayanni (2003)

Perceived No traffic encounter (BR4, BR6, n.a. benefits

\begin{tabular}{ll} 
IR4, PT8) & \\
\hline No tiredness from purchase (BR6) & n.a. \\
\hline Escaping from bad weather & n.a.
\end{tabular}
conditions (PT1)

\begin{tabular}{|c|c|}
\hline Search convenience (IR1) & $\begin{array}{l}\text { Ayanso et al. (2010), Punj and } \\
\text { Moore (2009), Rohm and } \\
\text { Swaminathan (2004) }\end{array}$ \\
\hline $\begin{array}{l}\text { Product comparison (IR1, IR2, } \\
\text { IR8, IR9) }\end{array}$ & $\begin{array}{l}\text { Silva et al. (2019), Shergill and } \\
\text { Chen (2005) }\end{array}$ \\
\hline $\begin{array}{l}\text { More useful and reliable informa- } \\
\text { tion (IR5, IR7, IR8, IR9, PT1) }\end{array}$ & n.a. \\
\hline $\begin{array}{l}\text { Escaping from not enjoyable } \\
\text { environment of some physical } \\
\text { stores (BR3, BR9) }\end{array}$ & n.a. \\
\hline Enjoyment (IR7, IR8) & $\begin{array}{l}\text { Bhatnagar and Ghose (2004), } \\
\text { Childers et al. (2001), Menon and } \\
\text { Kahn (2002), Forsythe et al. (2006), } \\
\text { Arnold and Reynolds (2003), } \\
\text { Wolfinbarger and Gilly (2001), } \\
\text { Rohm and Swaminathan (2004) }\end{array}$ \\
\hline $\begin{array}{l}\text { Home/office delivery (BR3, BR4, } \\
\text { BR9, PT1, PT2, PT9) }\end{array}$ & n.a. \\
\hline On time delivery (BR4) & n.a. \\
\hline $\begin{array}{l}\text { No parking problems (BR4, PT2, } \\
\text { PT8) }\end{array}$ & n.a. \\
\hline Avoiding queues (PT2) & Karayanni (2003) \\
\hline $\begin{array}{l}\text { Having no confusions while } \\
\text { purchasing (PT2) }\end{array}$ & n.a. \\
\hline
\end{tabular}


I tried to buy from [a foreign online store] because of the prices, they are much more appealing than in the existing physical stores in Portugal. (...) It makes no sense to spend more time and money when we can buy the same thing online, and it is cheaper and delivered to your home (PT9).

Hence, while buying perfume online for some participants was a natural consequence of their frequent online purchases, others typified bargain seekers, whom Ganesh et al. (2010) described as price oriented that often enjoy looking for bargains. Clearly, the perceived risks and benefits of purchasing perfume online vary among these two segments, as evidenced in the next sections.

\subsection{Perceived Risks of Buying Perfume Online and Strategies to Overcome Them}

Risk was a topic often raised by the interviewees, in line with the insights found in the literature. In this study, financial risk was the most cited, particularly with respect to international e-commerce sites that participants are unfamiliar with. One of the fears shared by the participants regarding unknown e-stores is not receiving the perfume, receiving counterfeit products, and not getting the refund. One of the participants explained this in detail:

I don't buy frequently because I still fear that the website is not legal and that we end up having a financial loss. (...) I prefer to buy from Brazilian stores, known ones, because your reimbursement is guaranteed, right? (...) Once I bought [from a foreign e-commerce store] because it was a promotion for half the price. We got a little afraid, right? Because it was an imported perfume, and then the perfume arrived, and we wondered if it was a fraud or not (BR4).

Participant PT8 also stressed on the performance risk. She was afraid the products bought online might not be similar to the ones she had bought in brick-and-mortar stores. These findings are in line with the work of Silva et al. (2019) and Bình (2018) who asserted the prevalence of perceived risks associated with e-shopping, namely financial and performance risks. In relation to this issue, several participants shared that they dealt with these perceived risks by choosing national stores and buying from known online stores even if the price is not the lowest. Responses from the participants served as illustrations as follows:

I prefer known stores, for trust reasons (PT9). 
I buy only at [a well-known international store chain], my criterion is not the price, it is the store, really. (...) I always search on well-known websites, and I only buy from these e-stores (BR5).

A number of the respondents also relied on friends' recommendations and experience with foreign online stores and bought less expensive perfumes to reduce the perceived risk. Responses from participants BR2 and IR2 illustrate this point:

At first I only bought in well-known stores. I prefer national stores, but (...) I have bought from a store I did not know based on friends' recommendations (BR2).

I buy less pricy perfume online, while prefer to buy more expensive ones in person, from a physical store (IR2).

Although the online buying behaviour of perfume has similarities to general online shopping, this study confirmed that perfume caused additional difficulties as an experience product; therefore, several strategies for overcoming these difficulties were adopted, for example, buying only known perfumes, gaining online experience with other goods before buying perfume, trying the product in physical stores before buying online and buying from known retailers. In addition, peer recommendations may help mitigate concerns with the reputation of online stores.

\subsection{Perceived Benefits of Buying Perfume Online}

With regards to the perceived benefits of buying perfume online, participants in this study highlighted several aspects to explain their shopping behaviours. The main advantages for choosing online stores to purchase perfume are generally similar to those for other products, and they are mostly financial and convenience. The participants acknowledged it was much cheaper to buy perfumes and cosmetics online. They admitted that without the huge discounts, they would not be able to purchase certain brands of perfumes. This demonstrated that online purchasing resulted in spending less and provided opportunities for consumers to access new and high-end products. Consequently, this study concluded that the perceived financial benefits were very important in explaining online purchase of perfume. The findings corroborated those by researchers such as Sharma et al. (2019, Silva et al. (2019) and Zhang et al. (2017). The following responses illustrate these points: 
I buy perfumes online for the same reason as other types of products. Firstly, convenience, it is much easier to buy online, I don't have to go to stores or search for products in the stores. And secondly, discounts (PT9).

It is time saving and the prices are lower (IR9).

Easily 50 per cent discount, even more (PT4, PT5 and PT6).

The price was lower than physical stores at that time (IR3).

The fact that the online channel provides rich information sources is also indicated in this study. One of the respondents stated that he valued the detailed information on perfume that was offered by e-commerce stores, something that is not easily available in physical stores. Descriptions of the products' components, comments and opinions of other customers always assisted his decision process regarding perfume, especially if he was considering a new product. Another respondent also indicated that the online features facilitated search, making it easy for her to find the desired perfume. Consequently, such richness of information offered by perfume e-tailers as found in the current study was also in agreement with those revealed by Forsythe et al. (2006) and Rohm and Swaminathan (2004). As indicated by Participant IR5, richness of information you can access online.

The participants also brought up another perceived benefit of buying perfume online-diversity. They indicated that some of the perfumes sold online were not available in their local physical stores, reflecting the same features of online shopping shown by Sharma et al. (2019), Silva et al. (2019) and Zhang et al. (2017). The responses by several participants are illustrated below:

More options to choose from (IR7).

The opportunity to buy imported perfume (BR6).

Although almost all the benefits and risk features of online purchase of perfume discussed here are congruent with those of other products usually offered online, there are still aspects that seem to be specific to perfumes. One of the most noticeable arguments was presented by participant IR1 and IR7, who were practically less sensitive to choosing scents for others, namely gift giving, than on those occasions where he intended to buy for his own consumption, as follows:

For myself, I still buy perfume online that I already know the fragrance. For others, I consider price and the brand of that perfume. As a gift, as 
I do not know what type of fragrance she/he likes, I do not consider the type of fragrance (IR1).

I have also bought just based on the appearance of the bottle shape, packaging or brand name. Of course this happened to me when I wanted to give it as a gift (IR7).

Hence, buying for others is also a facilitator for online shopping behaviour in the case of perfume because it may reduce perceived risks associated with not trying the perfume before buying. In brief, Table 4 illustrates the perceived benefits and risks of online shopping of perfume. Overall, this study provided empirical support for extant literature (see Table 4) regarding the set of perceived benefits and risks of online shopping which, as expected, were also similar to buying perfume in online stores. As demonstrated in this section, the benefits that stood out from the participants' narratives were financial ones, although several aspects related to convenience and information access were acknowledged. As expected, the inability to test the perfume before purchase stood out as a major perceived risk. Participants' narratives suggested that this was beyond product performance risk as it was not merely about the quality of the product but was actually related to the sensorial nature of choosing a perfume, particularly when the consumer was considering buying an unknown scent.

\subsection{Comparison of the Three Countries}

By looking at the profiles and accounts of the participants (Tables 2, 3 and 4) from the angle of three distinct cultures, it was easy to note the similarities and differences among the subsamples. Analysis of the interviewees' narratives revealed that Iranians perceived the most benefits of general online shopping (30 mentions), followed by the Brazilians (24 mentions) and the Portuguese (20 mentions). Additionally, the specific accounts on perceived benefits and risks of online shopping of perfume showed that the Iranians were most inclined to report benefits ( 25 mentions), while the figures for the Brazilians and Portuguese were 18. The greater similarity of the figures for Brazil and Portugal might be partially related to the shared culture of the two countries. Furthermore, the Portuguese respondents reported the least amount of perceived risks, which is in contrast with their nation's score on uncertainty avoidance. According to Hofstede Insights (2020), Portugal's score of uncertainty avoidance is the highest among the 
Table 4: Perceived Benefits and Risks of Perfume Online Shopping

\begin{tabular}{|c|c|c|}
\hline $\begin{array}{l}\text { Consumer } \\
\text { behaviour }\end{array}$ & Findings & Supporting Studies \\
\hline
\end{tabular}

Convenience (BR1, BR4, BR7, BR9, Bhatnagar and Ghose (2004),

IR4, IR5, IR7, PT1, PT5, PT8, PT9) Childers et al. (2001), Menon and

Search convenience (PT9) Kahn (2002), Sharma et al. (2019),

Zhang et al. (2017), Karayanni

(2003)

Price/Saving money (BR1, BR2,

Bhatnagar and Ghose (2004),

BR3, BR4, BR6, BR7, BR8, IR2, IR3,

IR4, IR5, IR6, IR7, IR8, IR9, PT2,

Childers et al. (2001), Menon and

PT3, PT4, PT5, PT6, PT7, PT8, PT9)

Kahn (2002), Close and Kukar-

Kinney (2010), Silva et al. (2019),

Sharma et al. (2019), Zhang et al.

(2017)

Perceived Saving time (BR4, BR7, BR9, IR2, Silva et al. (2019), Rohm and benefits IR3, IR5, IR7, IR9, PT1, PT8, PT9) Swaminathan (2004), Karayanni (2003)

Information richness (BR4, IR5, n.a.

IR7, IR8, IR9, PT9)

Product diversity (BR6, IR6, IR7) Bhatnagar and Ghose (2004),

Access to products that are

Childers et al. (2001), Menon and

unavailable in physical stores

Kahn (2002), Silva et al. (2019),

(BR5, IR1, IR2, IR7, PT1)

Rohm and Swaminathan (2004),

Sharma et al. (2019), Zhang et al.

(2017)

Access to imported products (BR6) n.a.

\begin{tabular}{|c|c|c|}
\hline \multirow{5}{*}{$\begin{array}{l}\text { Perceived } \\
\text { risks }\end{array}$} & Financial loss (BR4, BR7, BR8) & Silva et al. (2019) \\
\hline & Fake products (BR4, IR1, IR4, PT8) & Silva et al. (2019), Bình (2018) \\
\hline & Refund difficulties (BR4, IR4) & Vellido et al. (2000) \\
\hline & $\begin{array}{l}\text { Trust to online seller (BR2, BR3, } \\
\text { BR5, IR2, PT9) }\end{array}$ & Silva et al. (2019), Bình (2018) \\
\hline & $\begin{array}{l}\text { Consumers' inability to test a } \\
\text { new perfume before purchase } \\
\text { (BR1, BR3, BR5, BR6, BR7, BR8, } \\
\text { BR9, IR1, IR3, IR4, IR5, IR6, IR8, } \\
\text { IR9, PT1, PT2, PT4, PT6, PT8, PT9) }\end{array}$ & $\begin{array}{l}\text { Chiang and Dholokia (2003), } \\
\text { Phau and Poon (2000), Shergill } \\
\text { and Chen (2005), Zhang et al. } \\
\text { (2018) }\end{array}$ \\
\hline
\end{tabular}


three countries. Apparently, the fact that e-commerce is more accessible in Portugal compared with the other two nations, particularly from foreign online stores, may be one of the factors that contributed to lower perceived risks. Arbitrarily, by dividing the perceived benefits by perceived risks, the ratios are 1.2, 2.3 and 2.3 for Brazil, Iran and Portugal, respectively. The interpretation of the figures could be that the Iranians and Portuguese both saw the glass as "half full", while the Brazilians were inclined to see the online shopping glass as "half empty".

Interestingly, and despite the cultural and economic differences between the three countries, the findings tended to be consistent across the interviews, as narratives, arguments and experiences on perfume online shopping resonate across the data, independent of nationality. Obviously, consumers from the three countries also had clear similarities in terms of Internet access (Country ICT Data, n.d.), online purchase (OECD, 2017), and, in fact, were also characterised by a particularly dynamic perfume sector. Overall, data from the three countries provided additional validation for the findings and portrayed potentially globalised profiles of perfume e-shoppers that would be presented next.

\section{Discussion}

Based on the data collected for this study, three clear segments of perfume online shoppers are depicted (Figure 1). One group (the experienced e-shoppers) comprises consumers with a great deal of experience in online shopping, who buy perfume as naturally as they buy other products. Normally, they buy those perfumes they are familiar with and have experience using them. Some of them dislike going to brick-and-mortar stores, so the convenience offered by online retailers is particularly important to them.

Another distinct group (the bargain e-seekers) comprises people who often do not feel comfortable with Web shopping but are aroused by price discounts. They often buy perfume from specialised online outlets that either offer low prices or hold regular promotions. They tend to buy from a limited number of product categories online-the ones that are known for discounts. These two profiles are in line with the findings of Ganesh et al. (2010), who also identified bargain hunters as one of the e-shopper typologies based on consumers' motivations and perceptions. Still, this study succeeded in depicting the dynamism that underlines perfume online shopping behaviour. Indeed, this research 


\section{Experienced E-shopper}

- Frequently shops online

- Reduced perceived risks from online shopping

- Often prefers online stores

- Buys from international online stores

- Holds positive emotions toward online shopping

- Combine functional and non-functional motivations to shop online

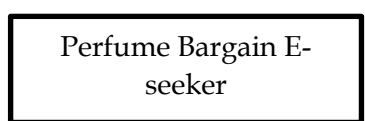

- Price oriented e-shopper

- Several perceived risks of online shopping

- Tends to buy only a limited number of product categories online

- Often driven by one single functional motivation (i.e. price)

- Prefers national and well-known e-stores but rapidly tries unknown international stores

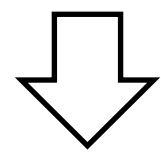

Buying perfume and other experience goods online is a natural consequence of growing experience with online shopping. The eshopper is an enthusiast with growing preference for online shopping.
E-shopping activity is driven by price differences between online and offline stores, which are particularly visible in some product categories. The bargain e-seeker has growing trust and experience in e-stores but prefers offline shopping.
Expert Perfume Eshopper

- Frequently buys perfume from international estores

- Looks for specialised online stores, including less known

- Has overcome perceived risks of online shopping

- Either an enthusiast for online shopping in general or buys only a few product categories online

- Clear positive emotions associated with perfume e-shopping

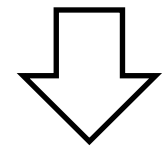

This profile can be derived from both a bargain e-seeker and e-shopper. This eshopper is confident of his/her expertise, is comfortable with buying perfume online, and willing to take some risks (e.g., buying from unknown stores and unknown products)

Figure 1: Perfume E-shopper Profiles

initiative also identified consumers who are perfume e-shopping experts. They buy from specialised stores, both international and unknown ones, who overcame perceived risks of buying perfume online, including new perfumes of unknown scent, and who have positive feelings of buying perfume online. Interestingly, and according to the narratives of the participants, this profile can be derived from e-shoppers whose confidence with online purchases grows and they gradually shop more categories of products from a larger number of online sellers. Expert perfume e-shoppers can also come from bargain e-seekers. Perfume is arguably one of the product categories most well-known for 
online discounts, and the positive experience of bargain e-seekers help to increase their confidence, overcome perceived risks and even discomfort in buying online. These may result in clear positive emotions associated with e-shopping, particularly in the categories and stores that offer the biggest discounts.

The findings from this study suggest that experience from one's past online purchase of other products is likely to facilitate the online purchase of perfume through the lowering of associated risks, especially those related to the financial and credibility of the e-seller. In addition, it is also possible to attract customers who predominantly prefer buying their perfume from conventional brick-and-mortar outlets by offering periodical discounts and holding sales promotions. Other triggers of online purchase behaviour include buying gifts, purchasing known perfume, purchasing from known sellers and trying offline before buying online.

\section{Conclusion}

This paper aims to fill a research gap found in the literature by exploring factors that facilitate online purchase of perfume. Data were collected by using a qualitative study involving perfume e-shoppers from Brazil, Iran and Portugal. It expands existing literature by identifying three distinct profiles of perfume e-shoppers based on the rich descriptions of the respondents' views and experiences. Although numerous studies (Chiang \& Dholokia, 2003; Choi et al., 2006; Hong \& Pavlou, 2014) have been conducted since the coinage of experience/search goods taxonomy by scholars such as Nelson (1970), the emergence of online sales platforms in recent decades still offer challenges on how best to offer certain products online with specific features, such as perfume in particular. In contrast to search goods, it appears that motivations and both perceived benefits and risks associated with buying experience goods online create some sort of arguable challenges for both e-buyers and e-sellers. The fact that there are only minor differences between the three categories of consumers provide an interesting contribution for the literature. Academicians tend to oscillate between the concepts of globalisation and the impacts of cultural differences on consumer behaviour. This study provides further evidence on global consumer cultures that may eventually prevail among online shoppers.

This study also provides an important insight into the dynamism

of consumer behaviour, which clearly needs more attention by academicians. It was found that some e-shopper profiles evolve into 
others over time, such as experience e-shoppers and perfume bargain seekers eventually become expert perfume e-shoppers. In addition, the increasing familiarisation with online shopping activities gradually enables consumers to be more comfortable and prefer to purchase experience goods online. This denotes the importance of considering the evolution of consumers' behaviour and profiles. Interestingly, several consumer behaviour theories, including the ones that supported this study, disregard the dynamic nature of consumer behaviour in the online context.

This paper provides several valuable inputs for managers, parti-cularly those in the perfume sector. The perceived benefits and risks of purchasing perfume online offer valuable cues on how managers can increase the efficacy of their online stores. One main trigger to improve sales of perfume online is price discounts, which is particularly important to people who are less experienced in making purchases online. Arguably, one segment of e-shoppers may always remain bargain seekers. Still, this study presents positive signs of the evolution of e-shoppers in terms of positive emotions associated with online purchases. Eventually, this group of consumers will give less importance to price benefits as they value other benefits of using the Internet to shop. As such, it is essential that e-stores implement strategies that provide a diversified set of benefits for their customers, those that deliver positive experiences and added value and can increase customer loyalty in the process. It is also recommended that the three segments of consumers be adequately approached with distinct strategies in order to not only satisfy them but also transform them from experienced e-shoppers and bargain e-seekers to e-shopping experts.

The findings from this study indicate that experience goods such as perfume should, in the initial stage, be sold in stores that offer an assortment of products and gradually deploy triggers such as discounts and cross selling to lead customers to include them in their online baskets for convenience reasons. The success of specialised international stores seems to be highly dependent on strong pricing strategies for most of the consumers (namely the experienced e-shoppers and bargain e-seekers), but may nurture expert e-shoppers by providing rich information, convenience, availability of a wider assortment of products and overall pleasant customer experience. Finally, the most significant perceived risk in purchasing perfume online is the inability of shoppers to test products before purchase. Arguably, this limits the ability of online stores to sell new perfumes as the description of scent is not 
sufficient for informed purchase decisions for most consumers. Hence, perfume online stores should consider alternatives to provide perfume testing, being omni-channel strategies (e.g., perfume testing in brick-andmortar stores), content strategies (such as providing descriptions and other forms of knowledge on the scent), and use customer relationship management (CRM) to regularly offer new product samples to their customers based on the types of scent they prefer and often buy.

Despite this study offers interesting insights, it is not without limitations. First, the results should not be generalised because they are based on qualitative data from only 27 consumers with prior experience of buying perfume online. Even though diversity of the subjects and data saturation was achieved, it is recommended that similar studies be conducted to further validate the results. The segment of perfume consumers who have never bought perfume online should also be considered in future research in order to give wider perspectives of perceptions and motivations associated with buying perfume using the Internet. One particular segment of perfume consumers that should be further researched involves those who frequently make online purchases of other products but not perfume. Different methodological approaches are also recommended for future research, such as using both qualitative and quantitative ones. Those countries that are renowned for both perfume consumption and the industry itself, such as France, Germany, Italy and the United States, could be good targets for future studies.

\section{References}

Ajzen, I. (1991). The theory of planned behavior. Organisational Behavior and Human Decision Processes, 50(2), 179-211. https://doi.org/10.1016/07495978(91)90020-T

Arnold, M.J., \& Reynolds, K.E. (2003). Hedonic shopping motivations. Journal of Retailing, 79(2), 77-95. https://doi.org/10.1016/S0022-4359(03)00007-1

Ayanso, A., Lertwachara, K., \& Thongpapanl, N. (2010). Technology-enabled retail services and online sales performance. Journal of Computer Information Systems, 50(3), 102-111. https:// doi.org/10.1080/08874417.2010.11645412

Bhatnagar, A., \& Ghose, S. (2004). Segmenting consumers based on the benefits and risks of Internet shopping. Journal of Business Research, 57(12), 13521360. https:// doi.org/10.1016/S0148-2963(03)00067-5

Bilgihan, A., Kandampully, J., \& Zhang, T. (2016). Towards a unified customer experience in online shopping environments: Antecedents and outcomes. International Journal of Quality and Service Sciences, 8(1), 102-119. https:// doi.org/10.1108/IJQSS-07-2015-0054 
Bình, N.P. (2018). Grey markets in customer-to-customer transaction and social networking - The case of Vietnam. Asian Journal of Business and Accounting, 11(2), 277-314. https://doi.org/10.22452/ajba.vol11no2.9

Bleier, A., Harmeling, C.M., \& Palmatier, R.W. (2019). Creating effective online customer experiences. Journal of Marketing, 83(2), 98-119. https://doi. org/10.1177/0022242918809930

Bryman, A. (2012). Social research methods (4th Ed.). Oxford University Press.

Chang, H.H., Fu, C.S., \& Jain, H.T. (2016). Modifying UTAUT and innovation diffusion theory to reveal online shopping behavior: Familiarity and perceived risk as mediators. Information Development, 32(5), 1757-1773. https://doi.org/10.1177/0266666915623317

Chiang, K.P., \& Dholokia, R.R. (2003). Factors driving consumer intention to shop online: An empirical investigation. Journal of Consumer Psychology, 13(1\& 2), 177-183. https:/ / doi.org/10.1207/S15327663JCP13-1\&2_16

Childers, T.L., Carr, C.L., Peck, J., \& Carson, S. (2001). Hedonic and utilitarian motivations for online retail shopping behavior. Journal of Retailing, 77(4), 511-535. https:// doi.org/10.1016/S0022-4359(01)00056-2

Choi, S.Y., Choi, B., \& Lee, H. (2006). Categorizing commercial products for customer oriented online retailing. Computers $\mathcal{E}$ Industrial Engineering, 51(1), 90-101. https://doi.org/10.1016/j.cie.2006.07.001

Clement, J. (2020). Share of Internet users who have purchased selected products online in the last 12 months as of 2018. https://www.statista.com/ statistics/276846/reach-of-top-online-retail-categories-worldwide/

Clemons, E.K., Wilson, J., Matt, C., Hess, T., Ren, F., Jin, F., \& Koh, N.S. (2016). Global differences in online shopping behavior: Understanding factors leading to trust. Journal of Management Information Systems, 33(4), 1117-1148. https://doi.org/10.1080/07421222.2016.1267531

Close, A.G., \& Kukar-Kinney, M. (2010). Beyond buying: Motivations behind consumers' online shopping cart use. Journal of Business Research, 63(9-10), 986-992. https://doi.org/10.1016/j.jbusres.2009.01.022

Country ICT Data. (n.d.). International Telecommunication Union. https:// www.itu.int/en/ITU-D/Statistics/Pages/stat/default.aspx

Dai, B., Forsythe, S., \& Kwon, W-S. (2014). The impact of online shopping experience on risk perceptions and online purchase intentions: Does product category matter? Journal of Electronic Commerce Research, 15(1), 13-24.

Diallo, M.F., Diop-Sall, F., Djelassi, S., \& Godefroit-Winkel, D. (2018). How shopping mall service quality affects customer loyalty across developing countries: The moderation of the cultural context. Journal of International Marketing, 26(4), 69-84. https:/ / doi.org/10.1177/1069031X18807473

Eurostat (2018). Digital economy $\mathcal{E}$ society in the EU: A browse through our online world in figures. https://ec.europa.eu/eurostat/cache/infographs/ict/ index.html

Forsythe, S., Liu, C., Shannon, D., \& Gardner, L.C. (2006). Development of a scale to measure the perceived benefits and risks of online shopping. 
Journal of Interactive Marketing, 20(2), 55-75. https://doi.org/10.1002/ dir.20061

Ganesh, J., Reynolds, K. E., Luckett, M., \& Pomirleanu, N. (2010). Online shopper motivations, and e-store attributes: An examination of online patronage behavior and shopper typologies. Journal of Retailing, 86(1), 106115. https:// doi.org/10.1016/j.jretai.2010.01.003

Gentile, C., Spiller, N., \& Noci, G. (2007). How to sustain the customer experience: An overview of experience components that co-create value with the customer. European Management Journal, 25(5), 395-410. https:// doi.org/10.1016/j.emj.2007.08.005

Grand View Research (2019a). Perfume market size, share \& trends analysis report by product (mass, premium), by end user (men, women), by distribution channel (offline, online), by region, and segment forecasts, 2019 - 2025. https://www.grandviewresearch.com/industry-analysis/ perfume-market

Grand View Research (2019b). Perfume market size worth $\$ 40.9$ billion by 2025 . https://www.grandviewresearch.com/press-release/global-perfume market Gray, D.E. (2004). Doing research in the real world. Sage Publications.

Guru, S., Nenavani, J., Patel, V., \& Bhatt, N. (2020). Ranking of perceived risks in online shopping. Decision, 47, 137-152. https://doi.org/10.1007/s40622020-00241-x

Ha, N.T., Nguyen, T.L.H., Nguyen, T.P.L., \& Nguyen, T.D. (2019). The effect of trust on consumers' online purchase intention: An integration of TAM and TPB. Management Science Letters, 9(9), 1451-1460. https://doi. org/10.5267/j.msl.2019.5.006

Hofstede, G. (1991). Empirical models of cultural differences. In N. Bleichrodt \& P.J.D. Drenth (Eds.), Contemporary issues in cross-cultural psychology (pp. 4-20). Swets \& Zeitlinger Publishers

Hofstede Insights. (2020). Compare countries. https://www.hofstede-insights. $\mathrm{com} /$ product/compare-countries/

Hong, Y., \& Pavlou, P.A. (2014). Product fit uncertainity in online markets: Nature, effects and antecedents. Information Systems Research, 25(2), 328344. https://doi.org/10.1287/isre.2014.0520

Ing, G.P., \& Ming, T. (2018). Antecedents of consumer attitude towards blogger recommendations and its impact on purchase intention. Asian Journal of Business and Accounting, 11(1), 293-323. https://doi.org/10.22452/ajba. vol11no1.10

Karayanni, D.A. (2003). Web-shoppers and non-shoppers: Compatibility, relative advantage and demographics. European Business Review, 15(3), 141152. https://doi.org/10.1108/09555340310474640

Ko, H., Jung, J., Kim, JY, \& Shim, S.W. (2004). Cross-cultural differences in perceived risk of online shopping. Journal of Interactive Advertising, 4(2), 2029. https:// doi.org/10.1080/15252019.2004.10722084 
Lee, K-F., Haque, A., Maulan, S., \& Abdullah, K. (2019). Determining intention to buy air e-tickets in Malaysia. Management Science Letters, 9(6), 933-944. https://doi.org/10.5267/j.msl.2019.2.009

Levin, A.M., Levin, I.P., \& Heath, C.E. (2003). Product category dependent consumer preferences for online and offline shopping features and their influence on multi-channel retail alliances. Journal of Electronic Commerce Research, 4(3), 85-93.

Menon, S., \& Kahn, B. (2002). Cross-category effects of induced arousal and pleasure on the internet shopping experience. Journal of Retailing, 78(1), 3140. https:/ / doi.org/10.1016/S0022-4359(01)00064-1

Nakayama, M., Sutcliffe, N., \& Wan, Y. (2010). Has the web transformed experience goods into search goods? Electronic Markets, 20(3-4), 251-262. https:// doi.org/10.1007/s12525-010-0041-z

Nelson, P. (1970). Information and consumer behavior. Journal of Political Economy, 78(2), 311-329. https://doi.org/10.1086/259630

Nepomuceno, M.V., Laroche, M., \& Richard, M.O. (2014). How to reduce perceived risk when buying online: The interactions between intangibility, product knowledge, brand familiarity, privacy and security concerns. Journal of Retailing and Consumer Services, 21(4), 619-629. https://doi. org/10.1016/j.jretconser.2013.11.006

Nguyen, D.H., de Leeuw, S., \& Dullaert, W.E. (2018). Consumer behaviour and order fulfilment in online retailing: A systematic review. International Journal of Management Reviews, 20(2), 255-276. https://doi.org/10.1111/ ijmr.12129

Nielsen (2018). Connected commerce: connectivity is enabling lifestyle evolution. https://www.nielsen.com/us/en/insights/report/2018/connectedcommerce-connectivity-is-enabling-lifestyle-evolution/

OECD. (2017). OECD digital economy outlook 2017, OECD Publishing. https:// doi.org/10.1787/9789264276284-en

Pappas, I.O., Kourouthanassis, P.E., Giannakos, M.N., \& Chrissikopoulos, V. (2016). Explaining online shopping behavior with fsQCA: The role of cognitive and affective perceptions. Journal of Business Research, 69(2), 794803. https://doi.org/10.1016/j.jbusres.2015.07.010

Pavlou, P.A., \& Fygenson, M. (2006). Understanding and predicting electronic commerce adoption: An extension of the theory of planned behavior. MIS Quarterly, 30(1), 115-143. https://doi.org/10.2307/25148720

Phau, I., \& Poon, S.M. (2000). Factors influencing the types of products and services purchased over the Internet. Internet Research: Electronic Networking Applications and Policy, 10(2), 102-113. https:/ / doi.org/10.1108/ 10662240010322894

Punj, G., \& Moore, R. (2009). Information search and consideration set formation in a web-based store environment. Journal of Business Research, 62(6), 644650. https:/ / doi.org/10.1016/j.jbusres.2007.04.013 
Rohm, A.J., \& Swaminathan, V. (2004). A typology of online shoppers based on shopping motivations. Journal of Business Research, 57(7), 748-757. https:/ / doi.org/10.1016/S0148-2963(02)00351-X

Seidman, I. (2013). Interviewing as qualitative research: A guide for researchers in education and the Social Sciences. Teachers College Press.

Shahbandeh, M. (2019). Global fragrance market. https://www.statista.com/ statistics/259221/global-fragrance-market-size/

Sharma, S., Menard, P., \& Mutchler, L.A. (2019). Who to trust? Applying trust to social commerce. Journal of Computer Information Systems, 59(1), 32-42. https://doi.org/10.1080/08874417.2017.1289356

Shergill, G.S., \& Chen, Z. (2005). Web-based shopping: Consumers' attitudes towards online shopping in New Zealand. Journal of Electronic Commerce Research, 6(2), 79-94.

Silva, J., Pinho, J.C., Soares, A., \& Sá, E. (2019). Antecedents of online purchase intention and behaviour: Uncovering unobserved heterogeneity. Journal of Business Economics and Management, 20(1), 131-148. https://doi.org/ 10.3846/jbem.2019.7060

Statista. (2020). Prestige fragrances. https://www.statista.com/outlook/ 21050300/100/prestige-fragrances/worldwide

Teo, T.S. (2006). To buy or not to buy online: Adopters and non-adopters of online shopping in Singapore. Behaviour \& Information Technology, 25(6), 497-509. https:// doi.org/10.1080/01449290500256155

Thomas, T., \& Carraher, C.E. (2014). A retail perspective on the shopping behavior, cultures and personalities for China, United Arab Emirates, Belgium, India, Germany and America. Journal of Technology Management in China, 9(3), 289-296. https://doi.org/10.1108/jtmc-08-2014-0050

UNCTAD (October, 2020). COVID-19 has changed online shopping forever, survey shows. https://unctad.org/news/covid-19-has-changed-online-shoppingforever-survey-shows

Vellido, A., Lisboa, P.J.G., \& Meehan, K. (2000). Quantitative characterization and prediction of on-line purchasing behavior: A latent variable approach. International Journal of Electronic Commerce, 4(4), 83-104. https://doi.org/10. 1080/10864415.2000.11518380

Venkatesh, V., Morris, M.G., Davis, G.B., \& Davis, F.D. (2003). User acceptance of information technology: Toward a unified view. MIS Quarterly, 27(3), 425-478. https:// doi.org/10.2307/30036540

Verhagen, T., \& Bloemers, D. (2018). Exploring the cognitive and affective bases of online purchase intentions: A hierarchical test across product types. Electronic Commerce Research, 18, 537-561. https://doi.org/10.1007/s10660017-9270-y

Verhoef, P.C., Lemon, K.N., Parasuraman, A., Roggeveen, A., Tsiros, M., \& Schlesinger, L.A. (2009). Customer experience creation: Determinants, dynamics and management strategies. Journal of Retailing, 85(1), 31-41. https://doi.org/10.1016/j.jretai.2008.11.001 
Wolfinbarger, M., \& Gilly, M.C. (2001). Shopping online for freedom, control, and fun. California Management Review, 43(2), 34-55. https://doi.org/ $10.2307 / 41166074$

Zhai, Q., Cao, X., Mokhtarian, P.L., \& Zhen, F. (2017). The interactions between e-shopping and store shopping in the shopping process for search goods and experience goods. Transportation, 44, 885-904. https://doi. org/10.1007/s11116-016-9683-9

Zhang, T., Ge, L., Gou, Q., \& Chen, L. (2018). Consumer showrooming, the sunk cost effect and online-offline competition. Journal of Electronic Commerce Research, 19(1), 55-74.

Zhang, W-G., Zhang, Q., Mizgier, K.J., \& Zhang, Y. (2017). Integrating the customers' perceived risks and benefits into the triple-channel retailing. International Journal of Production Research 55(22), 6676-6690. https:/ / doi.or g/10.1080/00207543.2017.1336679 
